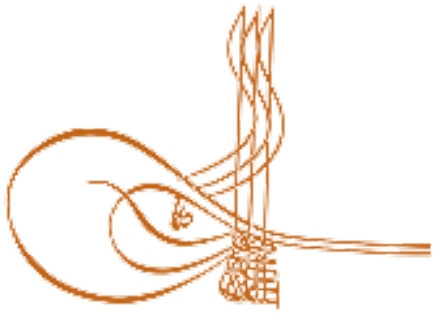

www.turkishstudies.net/education
Turkish Studies - Educational Sciences

eISSN: $2667-5609$

Research Article / Araştırma Makalesi

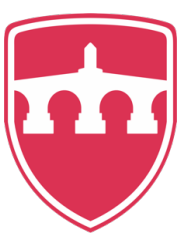

INTERNATIONAL

BALKAN

UNIVERSITY

Sponsored by IBU

\title{
Sevimli Mecmua Adlı Çocuk Dergisinde Çocuğa ve Eğitime Bakış"
}

\author{
A Perspective for Child and Education in a Children's Magazine: Sevimli Mecmua
}

\author{
Erhan Akdağ $^{* *}$ - Hilmi Uçan ${ }^{* * *}$
}

\begin{abstract}
Children's magazines have an important place in the publications for children. With the rich contents and visual elements these magazines are instruments of entertainment and education for children. These magazines, which have an important place in the development of reading skills with their rich content and visual elements, are an effective entertainment and learning tool for children. In our country, especially with the declaration of the Republic, the young republic has focused on these magazines that will educate and nurture their children culturally and artistically. In this period children's magazines, it is aimed to inform the readers and provide aesthetic pleasure with the sample texts selected from Turkish and world literature. In the fiveyear period from the declaration of the Republic to the acceptance of Latin letters, the children's magazines with Ottoman alphabet were aimed at giving the republican generation literacy skills and instilling Western values. Sevimli Magazine, which is among these magazines based on mind and science, stands out with its rich content and visuality compared to the period. Sevimli Magazine, which started publishing life by declaring that we do not have a quality magazine for children, contains many different types of texts for children. In this magazine, which aims to educate children while entertaining, there are many different literary genres such as story, fairy tale, theater, poetry, travel writing, biography, and activities such as cartoon, award-winning puzzle, street game, toy recipe, painting activity and question-answer corner. In this respect, it can be said that Sevimli Magazine prioritizes the child and education. In this study, which was carried out with the qualitative research method, it was aimed to evaluate the views about children and education in the Sevimli Magazine, which was published with the Ottoman alphabet. In this children's magazine where the child is highly cared and compared to the little man for the child, it is seen that constructivism is important in education.
\end{abstract}

\footnotetext{
* Bu çalışma "Sevimli Mecmua Adlı Çocuk Dergisi (Çeviriyazı, İnceleme)" adlı yüksek lisans tezinden üretilmiştir. 26-28 Ekim 2017 tarihleri arasında Antalya'da düzenlenen 6. Eğitim ve Öğretim Çalışmaları Dünya Kongresi'ndeki sözlü sunumun geliştirilerek tam metin hâline getirilmiş şeklidir.

** Dr., Afyon Kocatepe Üniversitesi, Eğitim Fakültesi, Türkçe ve Sosyal Bilimler Eğitimi Bölümü

Dr., Afyon Kocatepe University, Faculty of Education, Department of Turkish \& Social Sciences Education.

ORCID 0000-0003-3368-6064

erhanakdag@aku.edu.tr

${ }^{* * *}$ Prof. Dr., Afyon Kocatepe Üniversitesi, Eğitim Fakültesi, Türkçe ve Sosyal Bilimler Eğitimi Bölümü

Prof., Afyon Kocatepe University, Faculty of Education, Department of Turkish \& Social Sciences Education.

ORCID 0000-0001-7370-172X

ucan@aku.edu.tr

Cite as/ Atıf: Akdağ, E. \& Uçan, M. H. (2020). Sevimli Mecmua adlı çocuk dergisinde çocuğa ve eğitime bakış, Turkish

Studies - Education, 15(2), 595-609. https://dx.doi.org/10.29228/TurkishStudies.41630

Received/Geliş: 05 February/Şubat 2020

Accepted/Kabul: 25 April/Nisan 2020

Checked by plagiarism software

Copyright (C) INTAC LTD, Turkey

Published/Yayın: 30 April/Nisan 2020

CC BY-NC 4.0
} 
Structured Abstract: Magazines play an important role in child development. Children's magazines, which aim to entertain and provide information on many different topics, are among the frequently used resources in education with these features. With the proclamation of the Republic in Turkey, a children's magazine which was published in 1925 with the name of Sevimli Magazine had an important qualities and functions in that period. With this illustrated magazine, deficiencies in children's games, entertainment and education are tried to be completed. The lead author of the magazine, Sabiha Zekeriya, is an enlightened person who has seen Western education on the spot. Sabiha Zekeriya, who observed the approach of Westerners to children, thought that Turkish children should take their share of interest, love and entertainment just like them. According to her, the child should be seen as an adult after all. Unfortunately, in our perception, the child was a small, constantly transmitted entity. Sabiha Zekeriya tried to eliminate this deficiency in our country with her children's magazine. This magazine truly confronted readers with very rich and entertaining content. Sevimli Magazine stood out among children's magazines in its period with its rich content, diverse and fun applications. The magazine contained many texts and works that allowed children to learn while having fun. Sevimli Magazine offered its readers many different activities, from story to tale, handicraft to puzzle, street games to handmade toys, so that children could achieve active and fun learning. Emphasizing that children should be surrounded with love and above all, the magazine drew attention to the importance of learning by living and doing.

It can be seen that, Sevimli Magazine contains many important data about the child and education. The stories in this magazine show that the teacher-student relationship is not based on love. Schools are far from attracting students' interests and tastes. School principals have a hard discipline understanding. Lessons are monotonous. It is not possible to have fun learning in lessons. Students are passive, lack play and fun. Many children do not even have the opportunity to read. After the wars, many children remained orphans and they couldn't go to school. At this point, the magazine tries to support the educational needs of children. And it provides important information on many subjects from religious knowledge to important scientists in history. Students who subscribe to the magazine ask many questions, and the magazine even tries to answer questions from its readers. Some questions are about the human body and some of them are about geographical events. Sabiha Zekeriya also gives scientific answers to the readers.

The aim of the study: In this study, it was determined to be found that what kind of data does Sevimli Magazine contain related to children and education in the early years of the Republic of Turkey.

Method: In this study, which was carried out with the qualitative research method, it was aimed to evaluate the perspective of children and education in the Sevimli Magazine, which was published with the Ottoman alphabet in 1925. With the selection of 'children' and 'education' topics, all issues of the magazine were scanned and evaluated.

As a result, Sevimli Magazine is a magazine that tries to meet the needs of the children of the republic for their interest, love, curiosity, knowing, learning and entertainment. Sabiha Zekeriya draws attention to the importance that schools should be a home for love and that students can access information through active learning. The magazine includes information about happy children in developed countries and tries to guide Turkish children.

Keywords: Children's Literature, Child, Education, Ottoman-Lettered Children's Magazines, Sevimli Magazine.

Öz: Çocuklara yönelik yayınlar içerisinde çocuk dergilerinin önemli bir yeri vardır. Zengin içerikleri ve görsel unsurlarıly okuma becerisinin gelişiminde önemli bir yeri bulunan bu dergiler, çocuklar için etkili bir eğlenme ve öğrenme aracıdırlar. Ülkemizde özellikle Cumhuriyet'in ilanıyla birlikte 'genç cumhuriyet', çocuklarını eğitip kültürel ve sanatsal yönden besleyecek olan bu dergilere ağırlık vermiştir. Bu dönem dergilerinde Türk ve dünya edebiyatından seçilen örnek metinlerle okuyucuların bilgilendirilmesi ve estetik haz sağlaması amaçlanmıştır. Cumhuriyetin ilanından Latin harflerinin kabulüne kadarki beş yıllık süreçte Osmanlı alfabeli çocuk dergileri, cumhuriyet nesline okuma-yazma becerisi kazandırmak ve Batılı değerleri aşılamak amacı gütmüştür. Aklın ve bilimin temel alındığı bu dergiler arasında yer alan Sevimli Mecmua -dönemine nazaranzengin içeriği ve görselliğiyle öne çıkmaktadır. Bizde çocuklara ait nitelikli bir derginin bulunmadığını beyan ederek yayın hayatına başlayan Sevimli Местиa' da çocuklara yönelik birçok farklı türde metne yer verilmiştir. Çocukları eğlendirirken eğitmeyi amaçlayan bu dergide öykü, masal, tiyatro, şiir, gezi yazısı, yaşam öyküsü 
gibi edebî türlerle karikatür, ödüllü bulmaca, sokak oyunu, oyuncak tarifi, boyama etkinliği ve soru-cevap köşesi gibi pek çok farklı etkinlik yer almaktadır. Bu yönüyle Sevimli Mecmua'nın çocuğu ve eğitimi önceleyen bir dergi olduğu söylenebilir. Nitel araştırma yöntemi ile gerçekleştirilen bu çalışmada Osmanlı alfabesi ile yayımlanmış olan Sevimli Мecmua'da çocuk ve eğitim ile ilgili görüşlerin değerlendirilmesi amaçlanmıştır. Çocuğun oldukça önemsendiği ve çocuğa yönelik 'küçük adam' benzetmesinin yapıldığı Sevimli Mecmua'da, eğitimde yapılandırmacılığın önemsendiği görülmüştür.

Anahtar Kelimeler: Çocuk Edebiyatı, Çocuk, Eğitim, Osmanlı Alfabeli Çocuk Dergileri, Sevimli Mecmua.

\section{Giriş}

'Çocuk' insanoğlunun en değerli varlığıdır. Toplumların bilgi ve kültür birikimiyle beslenerek neslin sürerliğini sağlayan bu değerli varlık, medeniyetin köprüsü ve geleceğin mimarıdır. İyiliğin, doğruluğun ve çıkarsız sevginin merkezinde yer alan çocuk "saflığın ve temizliğin simgesidir. Çocuk denilince ilk akla gelen bu safiyettir, temizliktir. Çocuğun gözlerinin arkasında ikinci bir göz olduğunu düşünemezsiniz. Olduğu gibi ortadadır, önyargısızdır. Kimsecikler 'kral çıplak' demeye cesaret edemezken, 'kral çıplak' diyecek, diyebilecek saflıktaki varlıktır çocuk" (Uçan, 2005: 18). İçindeki bilme ve öğrenme arzusu onu sürekli sorular sormaya ve araştırmaya sevk eder. Bildiği ve öğrendiği sürece çocuk hem bilişsel ve duyuşsal gelişimini gerçekleştirir hem de mensubu bulunduğu kültürün, değerlerin ve inanç sisteminin aktarıcısı olur. Bu nedenle toplumlar, çocuklarının eğitimi üzerinde önemle durur ve onların kişilik gelişimlerinde kitaba, okumaya, edebiyata önemli işlevler yüklerler.

Duygu, düşünce, hayal ve izlenimlerin sözlü veya yazılı olarak güzel ve etkili bir biçimde anlatılması sanatı olan edebiyat (Kavcar, 2017: 108) çocuğun içindeki bilme ve öğrenme tutkusunu besleyerek ona yeni ufuklar açar. Bu noktada "çocukların büyüme ve gelişmelerine; hayallerine, duygularına, düşüncelerine, yeteneklerine ve zevklerine hitap eden, eğitirken eğlenmelerine katkıda bulunan sözlü ve yazılı verimlerin tamamı" (Yalçın ve Aytaş, 2016: 19) olarak tanımlanan çocuk edebiyatının önemli işlevleri bulunmaktadır. Çocuk edebiyatı ürünleri, hedef kitlesi olan çocuğun yaşamını zenginleştirmek, estetik zevkini geliştirmek ve ona pek çok konuda önemli bilgiler ve farkındalıklar sağlamak amacıyla ortaya çıkar. Edebî eserlerin uzam ve zaman bakımından sınırsız olması ve okuyucuyu sinırsız olay ve kişiyle tanıştırması çocuğun düşünce evreninin gelişmesini sağlar. Çocuğun dil gelişiminde özellikle ninni ve masalın; düşünsel gelişiminde de öykü, roman ve gezi yazısının rolü büyüktür. Ninni "doğrudan doğruya çocuklar için üretilmiş tek edebî türdür. Söz tarafı şiirin, ezgi tarafı müziğin alanına girer" (Ungan, Arıcı ve Şimşek, 2012: 163). Ses ve ahengin birlikteliği çocuğun ana dili sevgisini oluşturmanın önemli bir adımıdır. Ninniler ahenkli söylenişiyle "çocuğun ana dili sevgisini ve sözcük dağarcığını çoğaltan ve onun duygu dünyasını besleyen ürünlerdir" (Kıbrıs, 2010: 55). Ninni, çocuğu ana dilinin ahenkli söylenişiyle tanıştırırken aynı zamanda onun dinleme ve konuşma becerisinin de temelini atar. Dil becerisini geliştirmesi bakımından ninniler çocuk edebiyatı ürünleri arasında öne çıkar. Çocuğun hayal dünyasını geliştirmede masalın işlevi büyüktür. "Masal, öykü, roman gibi yaratılardaki kahramanların kendisiyle, çevresiyle, doğa ve toplumla yaşadıkları çatışmalar, toplumun benimsenen ya da karşı çıkılması gereken değerlerini, inançlarını okura sezdirir" (Sever, 2012: 65). Çocuk sezebildiği ölçüde duygu ve düşünce evrenini sağlıklı bir biçimde geliştirebilir. Masal, mutlu sonla bitmesi; iyiliği, doğruluğu salık vermesi bakımından çocuğun kişilik gelişimini olumlu olarak etkiler. "Çocuğun dünyasında masal, eğlendirici olduğu kadar eğitici bir rol de oynar. Güzellik duygusunun gelişmesine, iyilik arzusunun oluşmasına zemin hazırlar" (Şimşek, 2005: 75). Karşıtlıkları içermesi, neyin iyi ve doğru, neyin kötü ve yanlış olduğunu çocuğa eğlenceli biçimde sunması ve ögütler vermesi masalı diğer edebî türler arasında öne çıkarır. "Çocuk için yaşamın nesneleri, çevresindeki insanlar ve olaylar karşıt değerlerle vardır. İnsanlar ya iyidir ya kötüdür. Çocuğun değerler sistemindeki bu tek yanlı ve doğal bakış açısı, masalın benzer özellikleriyle örtüşmektedir" (Dilidüzgün, 1996: 32). Bu yönüyle masal; yaşamın farklılıklarını ve zenginliklerini bünyesinde 
barındıran, bunları da dinleyici ya da okuyucuya sezdirme amacıyla sunan oldukça eğlenceli bir türdür. Masal, çocuğun iyiyi, güzeli fark etmesini sağlarken merak unsuruna dayalı zengin olay örgüsüyle de oldukça ilgi çekici, zevkli bir türdür. "Çocuklar kendilerine anlatılan güzel bir masal veya hikâyeyi ilgiyle ve zevkle dinlerler. Beğendikleri bir kitabı ellerinden birakmak istemezler. Bunun sebebi, sanatın insanı derinden etkileme ve ruha nüfuz etme gücüdür" (Çılgın, 2007: 14). Kitapla, okumayla tanışmış bir çocuk duygu ve düşüncelerini geniş sözcük dağarcığıyla daha kolay dile getirebilir. Zengin söz varlığıyla doğru kullanılan dil de çocuğun ifade yeteneğini güçlendirir. Edebiyatla beslenmiş bir zihin, çevresine ve olaylara farklı açılardan bakma yetisini de kazanmış demektir.

Çocuğun hayal dünyasının zenginleşmesinde, okuma alışkanlığı kazanmasında, farklı olaylar ve durumlar karşısında özgün bir tutum geliştirmesinde ve insanı, yaşamı anlayabilmesinde öykü ve roman öne çıkan türlerdir. Bu iki tür, "çocukların sınırlı hayat tecrübelerini zenginleştirir; türlü insan tipleri üzerinde düşünmelerine imkân sağlar; geliştirmekte oldukları değer yargılarının daha açıklık kazanmasına yardımcı olur; böylece çocukların içinde yaşadıkları toplumsal ve kültürel ortama uymalarını büyük ölçüde kolaylaştırır” (Oğuzkan, 2013: 98-99). Öykü ve romanda 'her an her şeyin olabilirliği'ne dayalı merak unsuru, çocuğun zihninde türlü tasarım, çıkarsamalar yapmasına öncülük eder. Bu tasarım ve çıkarsamalarıyla çocuk, çok boyutlu düşünme yeteneğini de geliştirmiş olur.

Çocuk edebiyatı ürünleri arasında okurlara bilgi ve kültür aşılamada gezme eyleminin ve bu eylem esnasındaki gözlem gücünün ürünü olan (Arıc1, Ungan ve Şimşek, 2012: 280) gezi yazıs1 türünün de önemli yeri bulunur. Çocuğa çevresini ve dünyayı keşfetme olanağı sunan gezi yazıları ona bilmediği, görmediği yerler hakkında bilgiler sağlar. Gezi yazıları özellikle masal dönemini tamamlamış çocuklar için bilgilenmenin ve farklı coğrafyaları tanımanın anahtarı rolünü üstlenir. "Çocuk masal çağını geride bırakıp yakın çevresini tanımaya başladıkça, kendi çevresi dışında bir çevrenin, dahası başka ülkelerin de olduğunun ayrımına varır. Böylece çocuk kendi dünyasının dışında kalan bu dünyayı gezip görmek, tanımak gereksinimi duyar. İlgisini gezi yazılarına yöneltir” (Kıbrıs, 2010: 261). Çocuğun bu ilgisinde gezi yazılarının sözcüklerle resim çizme sanatı olan betimlemelere dayanmasının etkili olduğu düşünülebilir. Görmediği yerlerin gezi yazılarındaki zengin betimlemelerle gözü önüne getirilmesi çocuğun bilme ve öğrenme isteğini artırır ve hayal dünyasını besler. Tüm bu özellikleriyle ninni, masal, öykü, roman ve gezi yazısı çocuk edebiyatının etkili, eğitici, öğretici, eğlendirici ve estetik haz edindirici türlerini oluşturarak çocuk dergilerinde kendisine önemli bir yer bulur.

\section{Çocuk Dergileri}

Çocuk dergileri; zengin içerikleri, farklı edebî türleri barındırmaları ve ilgi çekici görsellikleriyle çocuk edebiyatının önemli kaynakları arasında yer alır. Bu dergilerde bilgi verme, edebî zevk aşılama, okuma-yazma becerisi kazandırma ve eğlendirme esastır. "Çocuklar için hazırlanan gazete ve dergiler her dönemde bu yaş grubunun ilgisini çekmiştir. Çocuk dergileri, aynı zamanda çocukların okuma alışkanlığı kazanması ve bilgilenmesinde de önemli işlevler yüklenmektedir. Çocukların günlük haber alma ve kalıcı bilgi edinmelerinde süreli yayınların büyük bir önemi vardır" (Gürel, Temizyürek ve Şahbaz, 2007: 248). Çocuk dergileri zengin içerikleriyle birer ansiklopedi niteliği taşımakta ve okurlarına birçok konuda önemli bilgiler sunmaktadırlar. Bu dergilerin hedef kitlesi olan çocukları yaşama hazırlamada üstlendikleri önemli rol şu sözlerle ifade edilir: "Çocuklarda bilgi, görgü ve genel kültürü geliştirir; toplumsal konulara, çevre ile ilgili olaylara dikkat çeker, çocukların hayata daha bilinçli olarak hazırlanmalarını sağlar"' (Şimşek, 2005: 26). Bu dergilerde çocukların eğlenirken öğrenmelerinin önü açılmakta ve düşünce dünyaları geliştirilmeye çalışılmaktadır.

Türk çocuk edebiyatı tarihinde Osmanlı alfabesi ile yayımlanmış çocuk dergileri incelendiğinde, bu dergilerin ninniden masala, öyküden romana, şiirden tiyatroya, gezi yazısından 
yaşam öyküsüne, bilmeceden bulmacaya, resimden karikatüre ve el işi çalışmalarına varıncaya dek oldukça zengin bir içerikle okurlarının karşısına çıktıkları görülür. 1 Kasım 1928'de Latin harflerine geçilmesiyle birlikte Osmanlı alfabeli çocuk dergileri ihmal edilmiş ve unutulmaya yüz tutarak işlev dış1 kalmıştır. Aradan uzun yıllar geçmesine rağmen günümüze dek çevirileri yapılmayan, incelenmeyen ve içerikleri bilinmeyen Osmanlı alfabeli çocuk dergilerimize yönelik Cüneyd Okay'ın şu tespiti dikkat çekicidir:

Osmanlı dönemi çocuk edebiyatı, üzerinde fazla çalışılmamış bir alan olmakla beraber eski harfli çocuk dergileri üzerine yapılan araştırmalar daha da yetersizdir. Bir iki makale, bir de bibliyografya hazırlama tekniğinden uzak, akademik ve bilimsel olmayan bir kitap çalışması hariç, çocuk dergileri gerektiği gibi bir ilgi görememiştir. Hâlbuki bu dergiler, eğitim tarihi ve çocuk edebiyatı için olduğu kadar sosyal tarih ve basın tarihi çalışmaları için ve hatta siyasi tarih çalışmaları için de çok önemli bir kaynak durumundadırlar (Okay, 1999: 8).

Osmanlı alfabeli çocuk dergilerimizin içeriğini "terbiye, ahlak ve eğitim ana temaları oluşturmaktadır. Ağırlıklı olarak eğitici bir özellik taşıyan bu dergilerde, eğitici ve ahlaki yazılara, okullardan haberlere, okuyucu mektuplarına, bilmecelere, hikâyelere, eşya ve hayvan tanıtımlarına, Osmanlı ve Avrupa basını hakkında bilgilere, yeni gelişmelere, keşiflere yer verilmiştir" (Gürel, Temizyürek ve Şahbaz, 2007: 254). Bu dergiler bir bakıma yayımlandıkları dönemin panoramasıdır. Geçmişteki değer yargılarımız, olaylara bakışımız, dünyayı algılayışımız, kısacası maddi ve manevi dünyamız -kültürümüz- pek çok yönüyle bu dergilerde yer alır. Çocukların beğenisini kazanmak için resim ve fotoğraflara, karikatürlere, hayvanlar âlemine geniş yer ayıran Osmanlı alfabeli çocuk dergileri, kendilerine "genellikle çocukların sevebileceği ya da çocuklukla ilgili şeyleri hatırlatabilecek isimler seçmişlerdir" (Okay, 1999: 23). Bu bağlamda Sabiha ve Mehmet Zekeriya Sertel çiftinin çıkardıkları Sevimli Mecmua gerek adı gerek zengin içeriği ve görselliğiyle çocukların beğenisini kazanma amacı güderek yayın hayatına başlar. 1925 yılının 1 Ocak'ında çıkmaya başlayan bu çocuk dergisi on beş günde bir perşembe günleri okurlarına ulaşır. Mehmet Zekeriya (Sertel)'nın sahibi olduğu Sevimli Mecmua'nın başyazarı Sabiha Zekeriya (Sertel)'dır. Dönemin aydın kişilerinden olan Zekeriya çiftinin yönetiminde dergi on sayı çıkar. On birinci sayıdan itibaren derginin müdürü Zeki Cemal'dir. Son iki sayıda Sevimli Mecmua'nın sahibi Nebizade Hamdi (Ahmet Hamdi Ülkümen)'dir. Mehmet Zekeriya Sertel, Sabiha Zekeriya Sertel ve Nebizade Ahmet Hamdi Ülkümen'in yaşam öyküleri incelendiğinde söz konusu kişilerin Avrupa'da, Amerika'da bulunarak yurt dışını iyi gözlemleme, inceleme şansı elde ettikleri görülür. Yayın hayatının içinden yetişen bu üç üretken kalem, genç cumhuriyetin yüksek tahsilli ve batılılaşma taraftarı kişilikleri arasında yer almaktadır. Batılılaşma, çocuk, eğitim konuları üzerine eğilerek Türk basın-yayın tarihinde birçok önemli gazete, dergi ve ansiklopedinin yayımlanmasına öncülük eden söz konusu yazarlar, döneminin başarılı bir çocuk dergisi olarak kabul gören Sevimli Mecmua'da oldukça zengin bir içerikle okurlarına seslenmeye çalışırlar. Ne var ki, 25 Haziran 1925'te tatile girilmesi nedeniyle derginin yeni sayısının çıkarılmayacağı bildirilir. On üçüncü sayısıyla da dergi okurlarına veda eder. Oldukça kısa süreli bir yayın hayatına sahip olan Sevimli Мecmua, on üç sayı boyunca kalitesinden ödün vermez. " 1925 'te yayımlanmaya başlayan Sevimli Mecmua o zamana kadarki çocuk dergilerinin geleneksel çizgisinden ayrılarak fotoğraf, karikatür, boyama köşesi, metinleri olmayan resimli öykülere yer verir" (Dedeoğlu, 2013: 300). Bu bakımdan Sevimli Mecmua yayımlandığı dönem içerisinde oldukça özgün bir yere ve niteliğe sahiptir. Cumhuriyet'in ilanından iki yıl sonra yayımlanan ve on üçüncü sayısıyla birlikte aynı yıl yayın hayatına veda eden bu dergi "gelişen bir insan yavrusu, olgunlaşmamış, 'reşit' sayılmayan küçük yurttaş” (Yörükoğlu, 2007: 13) olarak görülen 'çocuk'a ve 'eğitim'e yönelik döneme özgü algının aksine oldukça özgün düşünceler içermektedir. Sevimli Mecmua'da dönemin çocuk algısı, çocuk eğitimi, eğitim-öğretim anlayışı, öğretmen-öğrenci ilişkileri, farklı ülkelerdeki eğitim anlayışları vb. gibi daha pek çok konuda önemli bilgiler yer alır. 


\section{Yöntem}

Nitel araştırma tekniklerine uygun olarak yapılan bu çalışmada doküman incelemesi tekniği kullanılmıştır. "Doküman incelemesi, araştırılması hedeflenen olgu veya olgular hakkında bilgi içeren yazılı materyallerin analizini kapsar" (Yıldırım ve Şimşek, 2013: 217).

\section{Kapsam}

Çalışmanın kapsamını 1925 yılında on üç sayı olarak yayımlanan Sevimli Mecmua adlı Osmanlı alfabeli çocuk dergisinin tüm sayıları oluşturmuştur. Derginin birinci sayısındaki 'Sevimli Мecmua'yı Niçin Çıkarlyoruz?' başlıklı sunuş metni, dördüncü sayısındaki 'Kirpiklerimiz Neye Yarar' başlıklı bilgilendirme metni, yine dördüncü ve on ikinci sayısındaki 'Başka Milletlerin Çocukları Ne Yapıyorlar?' başlıklı tanıtım ve bilgilendirme metni, sekizinci sayısındaki 'Slfat Mektubu' başlıklı dil bilgisi çalışma metni çocuk ve eğitim başlıkları göz önünde bulundurularak çalışmanın sınırlılığını oluşturmuştur.

\section{Veri Toplama ve Analizi}

1925 yılında yayımlanan Osmanlı alfabeli çocuk dergilerimizden biri olan Sevimli Mecmua'nın tüm sayıları Ankara Millî Kütüphane'den temin edilerek Türkiye Türkçesine çevrilmiştir. Derginin tüm sayılarının 'çocuk' ve 'eğitim' başlıkları altında sınıflandırılarak incelenmesiyle çalışmanın verilerine ulaşılmıştır. Elde edilen veriler göz önüne alınarak bir çocuk dergisinden hareketle cumhuriyetin ilk yıllarında çocuğa ve eğitime yönelik bakış tespit edilmeye çalışılmıştır.

\section{Bulgular ve Tartışma}

$\mathrm{Bu}$ çalışmada, "Türkiye Cumhuriyetinin ilk yıllarında çıkan Osmanlı alfabeli çocuk dergilerinden Sevimli Mecmua'da eğitim ve çocuk nasıl ele alınmıştır?” sorusuna yanıt aranmıştır. Bu doğrultuda yapılan doküman incelemesi sonucunda elde edilen bulgular aşağıda sunulmuştur.

\section{Sevimli Mecmua'da Çocuk Algısı ve Eğitim}

Sevimli Mecmua'nın daha ilk sayfasında derginin başyazarı Sabiha Zekeriya (Sertel), bir anne şefkatiyle doğrudan çocuklara seslenir. Yazara göre Türk çocukları eğitimden, oyundan ve yetişkinlerin ilgi ve anlayışından uzak yetişmektedirler. Nitekim Sabiha Zekeriya, çocuğa toplumumuzda gerekli değerin verilmediğini şu sözleriyle dile getirir:

\footnotetext{
[...] şimdiye kadar çocuklarımız için iftihar verecek bir mecmua çıkmadı. Her İngiliz veya Alman çocuğunun iftiharla okuduğu kendisine mahsus bir gazetesi vardır. Siz bundan mahrumsunuz. Hayatta gidadan, mektepten, oyundan ve eğlenceden mahrum olan, küçük adam zannedilerek ihmal edilen siz Türk yavrularının iftihar edebileceğiniz bir mecmuaya sahip olmanızı istiyoruz (Akdağ, 2012: 18).
}

Bizim çocuklarımız kendilerine özgü yayınlardan, daha da önemlisi gıdadan, okuldan, oyundan ve eğlenceden yoksundurlar. Balkan, I. Paylaşım ve Kurtuluş olmak üzere peşi sıra üç büyük savaş veren, türlü yokluk gören ve buna rağmen egemenliğini yabancı boyunduruğuna bırakmayan böylesi bir milletin çocukları maddi açıdan ancak sınırlı olanaklara sahip olabilmiştir. Neredeyse küllerinden doğan genç bir cumhuriyetten bayındır olması beklenmese de yazarın sözünde asıl düşündürücü olan çocukların maddi yoksunluklarından öte manevi yoksunluklarıdır. Gıda ve okul maddi olanaklara dayalıyken oyun ve eğlence için bu durum pek de söz konusu değildir. Nitekim oyun ve eğlence için iki çocuğun bir araya gelmesi bile çoğu zaman yeterlidir. Çocuğun zihninde üstüne binilen bir dal parçası 'at'a, yerdeki çizgi 'seksek'e, bir bez parçası da 'bez bebek'e dönüşür ve çocuğun hayal dünyası olmazı olur kılar. Çocuklarımızın bu eksikliklerindeki temel etken onların değersiz (küçük adam) görülmeleri, kendileriyle yeterince ilgilenilmemesi ve çocuğun herhangi bir nesne ile kandırılabilecek bir varlık olarak görülmesidir. Özellikle toplumumuzda "çocuk kavramı da çocukluk çağı gibi belirsizlik ve çelişkilerle yüklüdür: Çocuk küçüktür ve aklı 
ermez; güçsüzdür, bilgisizdir, deneyimsizdir, saftır. Bu nitelikleri taşıyanlara da 'Çocuksun! Çocukluk etme!' denir. Kaygısızlık, mutluluk, masumluk, bilinçsizlik, yaramazlık sözleri çocukluğu çağrıştırır" (Yörükoğlu, 2007: 14). Oysaki toplumların teminatı olan çocuklara gerekli özgüvenin aşılanması, çocukların türlü edimlerinin ve becerilerinin geliştirilmesi medeniyetlerin ilerlemesinde anahtar rolü üstlenmektedir.

Çocuklara seslenişinde onların pek çok haktan yoksun bırakıldıklarını düşünen Sabiha Zekeriya, yazısının devamında bizlerin çocuk algısıyla Avrupalıların ve Amerikalıların çocuk algısını şu sözlerle karşılaştırır:

Başka milletler, çocuklarını, küçük adam değil, bütün milletin istikbalini elinde tutan en büyük adam diye tanırlar. Onlar için hayatta eksik olan her şeyi yaparlar. İşte ben başka milletlerin çocuklarına verdiği bu ehemmiyeti kıskanan bir Türk anasıyım. Sizin diğer sahalarda cevap veremediğimiz ihtiyaçlarınıza küçük mecmua ile kısmen olsun, cevap vermeye muvaffak olabilirsek vazifemizi yapmış oluruz (Akdağ, 2012: 18-19).

Sabiha Zekeriya'nın Türk çocuklarını Amerikalı akranlarıyla karşılaştırması 1919'da eşi Mehmet Zekeriya (Sertel) ile Amerika'ya giderek orada beş yıl kalmasına dayanmaktadır. Amerika'da bulunması yazarın çocuklara yönelik karşılaştırmalı gözlemler yapmasını ve farklı bir kültürün çocuğa bakışını kavramasını sağlar. Yazara göre başka milletlerde çocuk, bir yetişkin gibi karşılanır ve kendisine tıpkı bir yetişkin gibi davranılır. Gelişmiş toplumlar geleceğin çocukta gizli olduğunun bilincindedirler ve ona karşı duyarlıkla hareket ederler. Bizdeyse çocuk, ilgi ve gereksinimleri yeterince karşılanamayan, 'çocuktur, aklı ermez' düşüncesiyle geçiştirilen bir varlıktır. Sabiha Zekeriya'nın, o dönemin moda düşüncesi olan Batıc1lık'ın etkisiyle, genellemeye dayalı bu sözleri biraz abartılıdır. Ne var ki yazarın isteği, çocuğa hak ettiği değerin verilmesidir ve yayımlanan bu dergi ile çocuğun eğitimine katkı sağlamak amaçlanmaktadır. Sevimli Mecmua ile çocuk dergiciliğindeki önemli bir boşluk doldurulmaya çalışılır. Derginin ilk sayfasında yazarın çocuğu önemseyen ve ona değer veren bir üslupla okurlarına seslenme çabası onun çocuk duyarlığını gözler önüne serer.

Sevimli Mecmua'da Amerikan eğitim sistemine ilişkin oldukça önemli bilgiler yer alır. Sabiha Zekeriya, Amerika'daki bir anaokulunun fotoğraflarına yer vererek oradaki eğitimi değerlendirme yoluna gider. Dergideki 'Başka Milletlerin Çocukları Ne Yapıyor?' başlıklı bölümde yazarın Amerikan eğitimindeki yapılandırmacı yaklaşıma yönelik şu sözleri dikkat çekicidir:

Bu gördüğünüz resimler, Amerika'da bir yuvanın resimleridir. Burada çocuklara her şeyi kendileri yapmayı öğretirler. Bu mektebe gelebilecek bir çocuğun her işini kendi yapması şarttır. Onlara yalnız ev yapmak için lazım olan tahtayı, çekici, çiviyi verirler, hoca nasıl yapılacağını öğretir, sonra yalnız karşıdan seyreder. Çocuklar çekici ellerine vurur mu diye hiç düşünmezler (Akdağ, 2012: 23).

Sabiha Zekeriya'ya göre Amerika'daki çocuk yuvasının öğrencileri bir başkasının desteği olmadan kendi başlarına her işlerini görebilecek şekilde yetiştirilmektedir. Bu yuvadaki öğrenciler özgür bırakılmışlardır; kendilerine verilen bir görevi bağımsız düşünerek yerine getirirler. Öğretmen, öğrenciler için yalnızca yol göstericidir, onlara yeri geldiğince kılavuzluk eder. Burada çocuklar her şeyi 'yaparak' ve 'yaşayarak' öğrenirler, hatalarından ders alarak doğruya ulaşırlar ve başarmanın mutluluğuna erişirler. Sabiha Zekeriya, ilgili yazının devamında Amerika'daki çocuk yuvasıyla bizdeki okulları karşılaştırır ve okurlara "Sizin mektebiniz buraya benzer mi? Burası o memleketlerin mesut çocuklarının oyuncaklar içinde kendilerini kaybettikleri odadır. Onlar bahçeye benzeyen bu 1lık, bu şık ve bu temiz odada, kendi evlerinde imiş gibi, oynar ve eğlenirler. Ne mutlu onlara değil mi?" (Akdağ, 2012: 24) sorusunu yöneltir. Yazar, 'Sizin mektebiniz buraya benzer mi?' sorusuyla aslında çocuklara 'Yeryüzünde böyle eğitim yuvaları da var; ama şimdilik bize çok uzak...' demeye çalışır. 
Sevimli Mecmua'da 'Başka Milletlerin Çocukları Ne Yapıyorlar?' başlıklı bir başka yazıda yaparak, yaşayarak öğrenme okurlara şu sözlerle aktarılır: "Bu resimlerini gördüğünüz evi Amerika'da çocuklar mekteplerdeki yuvalarda yaparlar. Tahtalar fabrikada kesilmiş hazır olarak gelir. Onları birbirlerine geçirerek ev yaparlar. Bu resimde yapmaya çalıştıkları bir koltuktur. Kimi çivisini takar, kimi tahtasını geçirir. Kimi de boyar" (Akdağ, 2012: 187). Amerikalı çocuklar takım ruhuyla hareket eder ve tahtadan bir evle içinin döşemesini kısa sürede hazır hâle getirirler. Tamamlanan ev çocukların evcilik oyununa ve türlü eğlencesine hizmet eder. Yazının devamında Sevimli Mecmua'nın çocuklara aynı eğlence araçlarını sunma isteğinde olduğu şu sözlerle ifade edilir: "Sizin mektebinizde böyle oyuncaklar yoksa meyus olmayınız. Sevimli Mecmua size her nüshasında birkaç oyun ve oyuncak öğretiyor. Bu nüshadan itibaren bir de ev takımı hediye ediyor. Bunları yapınız, güzel vakit geçirirsiniz" (Akdağ, 2012: 187). Dergide yer alan tariflerle çocukların oyun ve oyuncak gereksinimi karşılanmaya çalışılır. Bu yönüyle Sevimli Mecmua çocukların eğitim faaliyetlerini zenginleştirmeyi amaçlayan bir dergi olarak öne çıkmaktadır.

Sevimli Mecmua'da eğitim konusu üzerinde özellikle durulduğu görülür. Türk uygarlık tarihinde eğitim sistemi 'terbiye' kavramının kökenbilimsel anlamına göre ş̧ekillendirilmeye çalış1lmıştır. Terbiye, 'Rab' sözcügünden türetilmiş bir sözcüktür; Rab sözcügü ise "sivrilikleri törpüleyen, sslah eden, aşırılıkları gideren" anlamlarını içerir. Eğitim "bireyin doğumundan ölümüne kadar süregelen bir süreçtir. Bu süreçte bireylere çeşitli bilgi, beceri, tutum ve değerler kazandırılır. $\mathrm{Bu}$ öğrenmeler bireyin davranışlarında gözle görülebilen değişikliklerde neden olur” (Erden, 2005: 15). Eğitim sürekliliğe dayanır ve Sabiha ve Zekeriya Sertel'e göre Amerikalı çocuk okuldan yaşama uzanan süreçte bu zengin donanımla karşılaşmaktadır. Yazar, bizdeki eğitimin Amerika'nın aksine zengin faaliyetlere, yaparak, yaşayarak öğrenmeye dayanmadığının bilincindedir ve eğitim alanındaki bu büyük boşluğu doldurmayı kendisine ilke edinir. Cumhuriyetin ilk yıllarında yayımlanan bir çocuk dergisinin böylesi önemli bir görevi üstlenip çocukların daha iyi eğitilmeleri için çaba göstermesi oldukça dikkate değerdir.

Sevimli Mecmua'da Amerikalı çocuğun aktif olduğu; neyi, nasıl yapacağına ve ne kadar öğreneceğine kendisinin karar verdiği belirtilir. Burada öğretmenin görevi çocuğu denetim altına alarak ona bilgi aktarmak değil, kılavuzluk etmektir. Amerika'da 'Çocuk eline çekici mi vuracak, vursun, vurmamayı öğrensin, böylece teknik aletleri kullanmada ustalaşsın’ anlayışı vardır. Bizdeyse çocuğa yasak koyucu ve onun gelişimine ket vurucu bir tutum söz konusudur. Sevimli Mecmua'ya göre, Amerika'da baskıcı ve engelleyici tutumlarla çocuk engellenmez. Orada eğitim "öğrenenin öğrenme sürecinin sorumluluğunu taşıdığı, öğrenene öğrenme sürecinin çeşitli yönleri ile ilgili karar alma ve özdüzenleme yapma firsatlarının verildiği ve karmaşık öğretimsel işlerle öğrenenin öğrenme sırasında zihinsel yeteneklerini kullanmaya zorlandığı bir öğrenme süreci” (Açıkgöz, 2006: 17) olan aktif öğrenmeyle gerçekleştirilir.

Dergide verilen bir diğer örnekte farklı yöntem ve tekniklerle öğrenim gören Amerikalı 'mutlu' öğrencilerin aksine bizdeki öğrencilerin 'mutsuz' oldukları anlatılır. Sabiha Zekeriya bizde öğretmen-öğrenci ilişkilerinin sevgisizlik ve azarlama üzerine kurulduğuna 'Hocasının Karikatürünü Yapan Kız' başlıklı yazısıyla dikkat çeker. 'Bir Kız Mektebinde Geçmiş Bir Vaka' kaydı düşülerek verilen bu öyküde, yatılı kı okulunda öğrenim gören Celile, sevmediği öğretmeni Makbule Hanım'ın karikatürünü yapar. Bu karikatürü gören öğretmenle öğrenci arasında geçen macerada Celile'nin şu sözleri bizdeki öğretmen/öğrenci ilişkisinin bozukluğunu gözler önüne serer: "İsabet... Şimdi görürse muhakkak beni azarlayacak. Fenalığa bak ki, gidip arayamam da. O zaman benim olduğunu anlar. Zaten beni sevmez. Fakat ben yine onu elime geçireceğim" (Akdağ, 2012: 48). Sevgisizlik üzerine kurulu bir eğitimde öğrenci, öğretmenden korkmakta ve kimi zaman da şiddet görmektedir. Dergideki 'Hocamı Nasıl Boyadım?' başlıklı monolog öğretmen korkusunu, dayağı işlemesi bakımından dikkat çekicidir. Bu anlatıda yatılı okuyan erkek öğrenci, öğretmeninden yediği dayak sonucunda ondan intikam almayı tasarlar. Öğrencinin şu sözlerinde öğretmene duyulan nefret gözler önüne serilir: 
Bir gün bir muzipliğim meydana çıktı, hocam kızdı, bir iyice tokatladı. Bu tokatların intikamını almaya ahdettim. O gece güzel bir plan hazırladım. Ertesi gün koğuşta kimse yokken yukarı çıktım, şiltenin kenarını yavaşça söktüm, büyücek bir parça pamuk çıkardım. Ayaklarımın ucuna basarak aşağı indim. Şimdi gece olmasını sabırsızlıkla bekliyordum (Akdağ, 2012: 413).

Yediği dayağın intikamını almak için öğretmeninin yastığına kırmızı mürekkepli pamuk koyan öğrenci sinsice hareket ederek bu kötü niyetini gerçekleştirir. Yastığa başını koyduğunda yüzü kırmızıya boyanan öğretmenin ağzından çıkan şu sözler eğitimimizdeki sevgi eksikliğine dikkat çeker:

- Bunu hangi alçak yaptı? Söyleyiniz bakayım!.. Şimdi hepinizi falakaya dizeceğim. Hepimiz yataklarımız üzerine oturduk... Çocukların kimi geriniyor, kimi esniyor, ne olduğunu anlamadıkları bu gürültünün sebebini âdeta birbirlerine soruyorlardı. Başımızı çevirdik, bir de ne görelim... Hocamın yüzünün yarısı kıpkırmızı kesilmiş! Çocuklar hepsi kahkaha ile gülüyorlardı. Hocam bunu işitince tekrar küplere bindi (Akdağ, 2012: 414).

Sabiha Zekeriya'ya göre çocuk bizde değeri anlaşılamamış, ilgi ve yetenekleri saptanamamış bir varlıktır. Amerika'da çocuğa verilen değerin ve sağlanan olanakların yüksek olduğuna değinen dergi, bunun somut örneğini Jackie Coogan adlı çocuk film yıldızıyla göstermeye çalışır. Sevimli Местиа' da bu küçük yeteneğin tanıtıldığı yazıda şu ilginç saptamada bulunulur:

Bu mazhariyet yalnız Ceki'ye münhasır değildir. Diğer milletlerin de sanatta muvaffak olmuş çocukları vardır. Bu sahifede gördüğünüz resimler muhtelif milletlerin küçük sanatkârlarını oyun oynarken göstermektedir. Kimi sinemada, kimi tiyatroda şöhret kazanmıştır. Rollere dikkat ederseniz görürsünüz ki bu küçük artistler hangi oyunu oynuyorlarsa o rolü benimsemişlerdir. Onlar bu muvaffakiyete ermek için küçükten talim görür, ders alırlar. Mekteplerde iken istidadı olanlar ayrılır, terbiye edilirler. Onların mazhar olduğu bu muvaffakiyete siz de erebilirsiniz. Belki içinizde onlardan daha çok muvaffak olacak kimseler vardır. Fakat bizde henüz bu istidadı göstermek için meydan yoktur (Akdă̆, 2012: 109).

Dergideki yazılardan Amerikan okullarında öğrencilerin gösterdikleri yetenek ölçüsünde farklı öğrenim dallarına yönlendirildiği anlaşılmaktadır. Buradaki okullar, ilgi ve yeteneğine göre öğrencileri yaşama hazırlayan kurumlar olarak öne çıkar. Yazının son cümlesinden bizde de pek çok yetenekli çocuğun var olduğu; ancak yetenekleri keşfedilmeyen bu çocukların körelip gittikleri sonucuna ulaşılır. Dergideki bu yazıyla okullarımızın ve eğitimcilerimizin çocukların ilgi ve yeteneklerini ortaya çıkaramadıkları, onları yaşama donanımlı, yeterli biçimde hazırlayamadıkları vurgulanır. Derginin eğitim/öğretimle ilgili getirdiği bu eleştiri yerinde bir eleştiri olarak kabul edilebilir.

Sevimli Mecmua'da yeteneklerinin ortaya çıkarılması bir yana, eğitim hakkı elde edemeyen çocuklardan da söz edilir. Sokak çocuklarının zorlu yaşamının anlatıldığı 'Sokaklardaki Kü̧̈ük Serseriler Nasıl Yaşar Hiç Düşündünüz mü?’ başlıklı yazıda kimsesizlik ve yoksulluk nedeniyle öğrenim göremeyen çocukların durumuna dikkat çekilmektedir. Söz konusu öykünün ön sözünde "Evinizde ve mektebinizde sıcak odada oynarken bir dilim ekmek için sokakta dolaşan serseri Küçük Osman'1 dinleyiniz. O size neler neler söyleyecek, neler öğretecektir" (Akdağ, 2012: 19) denilir. Babasını hangi savaşta kaybettiği belli olmayan, annesi de bir kaza sonucu ölen, köprü altlarına sığınıp hırsızlık yapan Küçük Osman'ın yaşamı bir ressamla tanışmasıyla tamamen değişir. Ressam, Osman'ın elinden tutar ve ona resim çizmeyi öğretir. Ressamın “ah, sen bir mektep görsen!..” sözü karşısında Osman'ın "O devlete ermek için bey oğlu, paşa oğlu doğmak lazım. Benim gibi sokak serserisinden yetişen ressama bu bile çok" (Akdağ, 2012: 21) sözü eğitimdeki fursat eşitsizliğini gözler önüne serer. Dergideki 'Ali'nin Bayramı' başlıklı bir başka öyküde de kimsesiz bir sokak çocuğu olan, cami köşelerinde dilenerek yaşamını sürdürmeye çalışan Rumeli göçmeni Ali'nin dramı 
anlatılır. Kimsesiz kalan Ali iyi bir eğitim alarak topluma yararlı birey olmak ister. Ne var ki kendisi gibi sokaklarda yaşayan arkadaşlarının ağzından dökülen şu sözler eğitim kurumlarımızın içler acısı durumunu göstermektedir: "Seni mektebe vermezler, verseler bile hocası var dayak atar, mürebbiyesi var azarlar, hademesi var çimdikler, neme lazım burada rahat rahat yaşarsın" (Akdağ, 2012: 284). Sokağın Ali için mektebe göre daha rahat, daha yaşanabilir bir yer olarak görülmesi bir hayli düşündürücüdür. Amerika'daki okullu, mutlu ve özgüvenli çocukların aksine toplumumuzda sokakların mutsuz çocuğu Ali'lerle karşılaşılmaktadır.

Sevimli Mecmua'daki 'Resimle Dünya Etrafinda Bir Seyahat' başlıklı gezi yazısında zengin bir tüccarın çocukları olan Togan ve Bilkay uçakla dünya seyahatine çıkar. İki kardeşin ilk durakları Azerbaycan'dır. Azerbaycan'daki açık hava okulunu görüp buraya imrenen kardeşler bizde neden böyle okulların bulunmadığını sorgularlar. Böylesi eğitim kurumlarının aksine, bizde Sevimli Мecmua'nın yayımlanışından on beş yıl sonra bile Anadolu okulsuz ve öğretmensizdir. Dönemin başbakanı İsmet İnönü’nün önderliğinde, Millî Eğitim Bakanı Hasan Âli Yücel tarafından İsmail Hakkı Tonguç'un çabalarıyla Köy Enstitüleri'nin kurulması ancak 1940'ta gerçekleşecektir. Bu okulların kurulmasından on beş yıl önce Sevimli Mecmua'nın hem açık hava okullarından hem de öğrencilerin yaparak, yaşayarak öğrenmelerinden bahsetmesi eğitim açısından büyük önem taşımaktadır. Togan ve Bilkay'ın Azerbaycan'daki açık hava okullarına ilişkin gözlem ve görüşleri dergide şu sözlerle dile getirilir:

- Değil mi onlar da Türkmüş, tabii bize benzerler. Bak, bak, bu açık hava mektebini çok beğendim. Keşke bize de yapsalar...

- Ben bu mektepleri işitmiştim, bu mektepleri dağlarda, ormanlarda yaparlar. Çocukların sınıfları bahçede olurmuş. Çocuklar, derslerini burada okur, yer, oynar, uyumak için de çadırlarına girermiş...

- Ne güzel, ne güzel...

- Bu mekteplerde çocuklar kendi işlerini kendileri görürmüş. Sabah yataktan kalkınca ellerini yüzlerini kendileri yıkar, kahvaltılarını hazırlar, bahçede ağaçlar altında yerlermiş. Yemekten sonra kaplarını kendileri yıkar, yataklarını yapar, yemeklerini pişiren kadına kendileri yardım edermiş. Mesela biri sebze ayıklar, biri yıkar, biri ağaçlardan odun toplar, öteki yakar, yemeklerini güle eğlene, hatta şarkı söyleyerek pişirirlermiş.

- Aman ne güzel şeyler... Bu mektepleri Azerbaycan'da yapmışlar da bizde niye yapmamışlar?..

- Onu döndüğümüz zaman babamıza sorarız. Bak, bu balık avlayan çocuğu görüyor musun? Ne güzel avliyor.

- Aman ben buralarını çok sevdim. Burada kalalım... (Akdağ, 2012: 36).

Sevimli Mecmua'da 'Başka Milletlerin Çocukları Ne Yapıyorlar?' başlıklı bir başka yazıda da Japon çocuklarının yaşamına ilişkin bilgiler verilir. Gelenek göreneklerine bağlılıkları, çalışkan olmaları, anne babalarının sözünü dinlemeleri dolayısıyla Japon çocukları övülür ve Türk çocuklarına örnek gösterilir. Dergide Japon çocuklarından hareketle okurlara temizliğin önemini aşılamak için "İçinizde bilmem yıkanmaktan korkanlar var mı?.. Hele Japon çocukları gibi sizi yıkasalar bilmem ne yapardınız. Japonlar temizliğe fevkalade meraklıdırlar. Evlerini katiyen boyatmaz, tahtada bırakır, tahtaları her gün iyice silerler. Eskiden bizde olduğu gibi bu temiz odalara ayakkabıyla girmezler" (Akdağ, 2012: 404) denilir. Bu yazının 'Eskiden' sözcüğüyle başlayan son cümlesi bizde bazı geleneklerin terk edilmesine bir serzeniş olarak düşünülebilir. Dergide Türk çocuklarına çalışkan olmayı aşılayan şu sözler oldukça dikkate değerdir:

Bir Japon için en büyük kusur tembel olmaktır. Çocukların tembelliğini ceza ile, tekdir ile değil şefkatle gidermeye çalışırlar. Bir aile tembel çocuğunu diğerlerinden ayırır, bir 
hasta gibi tedavi eder. Çocuk da cidden hasta olduğuna, tembelliğin bir hastalık olduğuna inanır. Hastalığının savması için annesinin tavsiyelerini dinler, tembellikten kurtulmak için âdeta mücadele eder ve muvaffak olur. Bugünkü büyük Japonya'yı işte bu mefkûreli gençler yapmıştır (Akdağ, 2012: 405).

Okurlarını tembellikten uzak durmaya sevk eden Sevimli Mecmua'da çocukların eğitimine yönelik yeme-içme kültüründen kişisel bakıma dek pek çok alanda eğitici yazılara da yer verilir. Derginin hemen her sayısında 'Sihhat Ülkesi' başlığıyla yer verilen yazılarda çocukların hangi gıdaları tüketip hangi gıdalardan kaçınmaları gerektiği vurgulanır. Sağlık konusunu çocukların daha kolay anlayabilmesi için özellikle somutlaştırmalar yapılır. Örneğin dergide bir 'Sıhhat Ülkesi'nin varlığından söz edilir. Bu ülkenin başkenti 'Süt Şehri'dir. Bu şehirde 'Kahve Kralı' savaşta yenilmiştir. 'Hazım Dağı' üzerinde tesis edilmiş 'Tatlı Su Şehri', 'Sıcak Su Kaplıcaları', 'Garbi Diş Fırçası Vilayeti', 'Portakal Ormanı', 'Ispanak Ormanı', 'Sıcak Çorba Membaı', 'Yetişmiş Patates Tepesi', 'Oyun Çayırı' ve 'Tatlı Uyku Dağı' vardır. Uyuyan çocuklar 'Rüya Şehri'ni seyredebilirler (Akdağ, 2012: 53). 'Sihhat Ülkesi'nde temel izlek sağlıklı büyümek isteyen çocukların bol bol süt içmesi, kahve içmekten kaçınması, dişlerini düzenli firçalaması, çorba içmesi, meyve-sebze yemesi, kırlarda oyunlar oynaması ve uyku saatlerini aksatmamasıdır. Cumhuriyetin çocuklarının sağlıklı beslenmesi ve ülkelerine faydalı, çalışkan bireyler olmaları derginin üzerine özenle eğildiği konular arasinda yer alır.

Sevimli Mecmua'da eğitime yönelik soru-cevap bölümleri de oldukça dikkat çekicidir. Başlangıçta çocuklara merak edebilecekleri konularda bilgi sunan dergi, dördüncü sayısında okurlarına şu açıklamada bulunur: "Bu nüshamızdan itibaren küçük karilerimizin müşküllerini hal için bir sütun açıyoruz, ailenizin, hocalarınızın halledemediği müşkül sualleriniz olursa bize sorunuz, size bu sütunlarda cevap vermeye çalışacağız" (Akdağ, 2012: 119). Bu yazının devamında 'Kirpiklerimiz Neye Yarar?' başlıklı soru şöyle cevaplanır:

Gözlerimizin etrafını saran ve uzunluğu nispetinde gözlerimize güzellik veren kirpiklerin ne işe yaradığını bilir misiniz? Kirpikler iki iş görürler. Evvela gözlerimizi güzelleştirmeye sonra da gözlerimizi korumaya yarar. Yorulduğumuz zaman alnımızdan akan terler, kirpiklerimiz olmasa, gözlerimizin içine akar. Eğer kirpiklerimiz olmasa bu ter damlaları gözümüze girecek, o vakit hem gözlerimiz yanacak hem de görmek kabiliyetimiz azalacak. Bundan maada dışardan gelen toza toprağa karşı gözlerimizi muhafaza eden de onlardır (Akdağ, 2012: 120).

İçeriğinde otuz karikatür, otuz dokuz öykü, yirmi masal, üç gezi yazısı, yedi yaşam öyküsü, otuz altı el işi etkinliği, dört kompozisyon yazma etkinliği, dokuz şiir, otuz altı oyun, yirmi bir tanıtım yazısı, on iki bulmaca, dört bilmece, on yedi soru-cevap, iki mektup, dört tiyatro (farklı iki piyese dayalı), farklı iki romana dayalı on altı roman çevirisi (Heidi, Dünya Etrafinda Seksen Günde Seyahat) bulunan ve yayımladığı bulmacaları çözen yedi yüz elliye yakın çocuğa da türlü ödüller veren Sevimli Mecmua'da bilimsel ve teknik konulardaki bilgilendirmelerin yanı sira Türkçenin eğitimi ve öğretimi üzerinde de özenle durulur. Dergi, dil bilgisi öğretimine yönelik yazma çalışmasına yer vererek 'Slfat Mektubu' başlıklı bir yazıyı okurlarına sunar. Bu çalışmada aşağıdaki mektuptaki boşluklara çocukların uygun sıfatları getirmeleri istenir.

“..." Kardeşim

Bayram bu sene hepimizi ... buldu. $\mathrm{Bu}$... havalarda seninle beraber kırlarda gezmeyi ne kadar isterdim. Sen şimdi kim bilir o ... çayırlarda o ... arkadaşlarınla ne ... günler geçiriyorsun. Kuzuları ... melemelerine, köy hayatında o ... letafetine hasret kaldım. İnşallah gelecek sene ben de sizi o ... hayatınıza iştirak edebilirim. Bu ... . . bayramını tebrik ile o ... ... gözlerinden öperim, kardeşim (Akdağ, 2012: 262).

Dergideki bu çalışma, çocukların hem yazma becerilerini geliştirmeyi hem edebî bir tür olan mektup yazımını göstermeyi hem de dil bilgisi öğretimini gerçekleştirmeyi hedeflemektedir. Sevimli Местиа'nın -1925 yılında- birden fazla kazanımı amaçlayan böylesi önemli bir dil bilgisi 
çalışmasına yer vermesi, çocuklara Türkçe öğretimi açısından da yararlı olmaya çalıştığının göstergesidir.

\section{Sevimli Mecmua'da Oyun ve Eğlence Yoluyla Eğitim}

Yapılandırmacı öğrenme yaklaşımının önemli unsurlarından birini de oyun oluşturur. Oyun "belli bir amaca yönelik olan ya da olmayan, kurallı ya da kuralsız olarak gerçekleştirilen her durumda çocuğun isteyerek katıldığ fiziksel, zihinsel, dil, duygusal ve sosyal gelişiminin temeli olan, gerçek hayatın bir parçası, çocuk için en etkin öğrenme süreci” (Çakmak ve Elibol, 2013: 8) olarak tanımlanmaktadır. Çocuğun bilgiyi işleme ve anlamlandırmasında yapacağı etkinliği özümsemesi ve bu etkinliğe katılımı etkilidir. Bu noktada oyun, bilginin işlenmesi ve kazanımında öne çıkar. Nitekim "çocuğun dünyasında oyunun yeri ve değeri [...] büyüktür. Oyunlar, çocuğun geleceğini hazırlayan, zekâ egzersizleri ve çocuk eğlenceleridir. Çocuk düşüncesi de oyunla başlar" (Şirin, 1998: 86). Oyun, çocuğun bilişsel, duyuşsal ve psiko-motor gelişimini destekleyen etkili bir eğlenme ve öğrenme aracıdır. Oyun sayesinde çocuk "en derin duygu ve gereksinmelerini ifade olanağı bulmakta ve sorunlarını kendi kendine çözebilmektedir. Çocuk, bebekleriyle evcilik oynarken, evin çeşitli bireylerine olan duygularını bu yolla açığa vurabilmektedir" (Yavuzer, 2011: 177). Oyun, çocuğu yaşama hazırlamada etkin bir rol üstlenir. "Freud ve Erikson'a göre, oyun çocuklara endişeler ve çatışmalarda ustalaşması için yardımcı olur. Gerilimler oyunda serbest bırakıldığı için, çocuklar yaşamın sorunlarıyla başa çıkabilirler. Oyun çocuklara aşırı fiziksel enerjiyi ve birikmiş gerilimleri boşaltma izni verir" (Sanders, 2008; akt. Santrock, 2012: 266-267). Psikomotor becerilerin gelişmesinin önünü açan oyun, çocukların bilişsel açıdan yetkinleşmesinin de etkili bir aracidır. Bu nedenle "Piaget (1962), oyunun çocuğun bilişsel gelişimini ilerlettiğini öne sürmüştür. [...] Oyun çocuklara yeterliliklerini ve kazanılan becerileri rahat, zevkli bir şekilde uygulama izni vermektedir. Piaget, bilişsel yapıların uygulanması gerektiğini ve oyunun bu uygulama için mükemmel ortamı sağladığını düşünmüştür” (Santrock, 2012: 267).

Sevimli Местиа' da etkili öğrenmenin önemli unsurlarından biri olan oyun geniş yer tutar. Derginin tüm sayılarında çocuklara oyunlar aracıllğıyla eğlenme ve öğrenme olanağ sunulur. Örneğin, dergide 'Kendi Kendinize Yapabileceğiniz Esrarengiz Bir Tahtelbahir' başlıklı yazıda suda batıp çıkan oyuncak denizaltı yapımı "Burada gördüğünüz tahtelbahir, kendi kendinize yapabileceğiniz küçük bir oyuncaktır. Fakat bu küçük oyuncağı suya bıraktığınız zaman hakiki bir tahtelbahir gibi dalıp çıktığını göreceksiniz. Bu tahtelbahri yapmak gayet kolaydır. Aşağıdaki tarifi dikkatle okuyunuz. Resmine de iyi bakınız. Sonra kendi kendinize bu tarif dâhilinde tecrübeye kalkınız" (Akdağ, 2012: 28) denilerek ayrıntılı bir şekilde anlatılır. Teknik bir resme de yer verilerek yapım aşamaları anlatılan denizaltı sayesinde çocuklar hem suyun kaldırma kuvvetini hem de denizaltının çalışma prensibini uygulamalı biçimde öğrenme olanağı elde etmektedirler. Okurlarına hemen her evde bulunabilecek basit malzemelerle kendi oyuncaklarını yapma olanağı sunması derginin etkili ve eğlenceli bir öğretim aracı olmayı amaçladığının göstergesidir.

Sevimli Mecmua, okurlarına oyuncak dışında türlü oyun hakkında da önemli bilgiler verir. Dergide 'Ev ve Bahçe Oyunları' başlığı altında birçok ev ve sokak oyununun açıklamasına yer verilmektedir. Örneğin, 'Mum Söndürme' başlıklı oyun için çocuklardan masanın üzerinde bir mumu ve bir kutu kibriti hazır bulundurmaları istenir. "Oyunculardan birinin gözlerini bağlayınız. Sonra mumum önüne getirip bir defa döndürünüz. İleri doğru bir, iki, üç adım atsın. Bir daha dönsün, sonra yine üç adımda masanın önüne gelip mumu söndürsün. Söndürmeye muvaffak olan vadedilen hediyeyi alır, söndüremeyenler oyunu kaybederler" (Akdağ, 2012: 305-306) açıklamasıyla okurlara anlatılan mum söndürme oyunuyla çocukların eğlenmelerinin yanı sıra yer ve yön algılarının da geliştirilmesi amaçlanmaktadır. Dergideki 'Hoş Bir Oyun' başlıklı bir başka yazıda "Oyuncular bir sıra teşkil ederler. Sıranın başında duran yanındakinin kulağına bir cümle söyler. O da aynı cümleye bir kelime ilave ederek yanındakine söyler. Bu suretle sıranın başındakine gelir. Sıra başı kulaktan kulağa gezerek kendine gelen cümleyi, ilk kendi söylediği hâlde, anlamaktan âciz kalır. Zira cümle 
tamamen değişir” (Akdağ, 2012: 406) tarifi yapılır. Çocukların dinleme becerilerini geliştirmeye yönelik bu oyun aynı zamanda hafızayı güçlendirme işlevi de taşır. Kulaktan kulağa dolaşan cümledeki değişim çocukların eğlenmelerine de olanak sağlar.

Sevimli Mecmua'da yer verilen birçok oyun açıklaması ve oyuncak tarifinin yanında çocuklara resim çizdirip boyama yaptırma da söz konusudur. Çocuk için boyama ve resim yapma önemlidir; çünkü "resim faaliyeti sırasında birey, konu seçimi ve yorumlamasıyla bize salt bir resim örneği vermemekte, resimden de öte bilgiler sunmaktadır. Çocuk bize resmiyle âdeta kendisinin bir parçasını yansıtmakta, olaylar hakkındaki duygu, düşünce ve görüş biçimlerini dile getirmektedir" (Yavuzer, 2011: 194). Dergide 'Bu Resimleri Boyayıp Gönderiniz. Bakalım Ne Dereceye Kadar Ressamsınız?' başlıklı çalışmalarla çocuklar resim yapma ve boyamaya özendirilir. Okurlarının küçük kas motor gelişimlerine katkı sağlamaya çalışan dergi, bu çalışmalarda başarı gösteren yetenekli çocuklara tüm sayılarında türlü ödül (kitap, çikolata, dolma kalem vs.) vermekten de geri durmaz.

Sevimli Mecmua'nın okurlarına sunduğu eğlence olanaklarından biri de çocukları ücretsiz olarak sinemaya davet etmesidir. "Sinemanın çocuğun psiko-sosyal gelişiminde bir uyarım kaynağı olduğu belirlenmiştir. [...] Sinemanın haz kaynağı olmasının, sinema alışkanlığının oluşmasının en büyük nedeni, filmin çocuklara günlük yaşamlarından farklı bir heyecan vermesidir" (Yavuzer, 2011: 218). Çocuklara sinema aracıllğıyla kültürel bir etkinlik olanağı sağlaması ve onların hayal dünyalarını zenginleştirmeye çalışması derginin önemli bir görev yüklendiğinin göstergesidir. 1925 'te yayımlanan bir çocuk dergisinin okurlarına ücretsiz olarak sinema davetiyesi vermesi, yayıncılık anlayışını tamamen çocuğun kişilik gelişimi üzerine dayandırdığını ortaya koymaktadır. Dergide 'Meccanen [Bedava] Sinema' başliklı ilanlarla "Bu haftadan itibaren ayda iki defa karilerimize meccanen sinema vereceğiz. Birinci sinemamız yarın Şehzadebaşı'nda Millî Sinema'da verilecektir. Sinema saat dokuz buçukta başlayacaktır. Bütün karilerimiz davetlidir. Geliniz görünüz. Para almıyoruz. Kupon istemiyoruz. Arkadaşlarınızı getiriniz" (Akdağ, 2012: 116) denilerek çocukların sinemaya davet edilmesi, genç cumhuriyetin çocuklarının görsel ve işitsel açıdan iyi yetişmelerinin amaçlandığını göstermektedir.

\section{Sonuç}

Sevimli Mecmua Cumhuriyet'in ilk yıllarında yayımlanmış Osmanlı alfabeli çocuk dergileri içerisinde gerek biçim gerek içerik açısından oldukça özgün ve seçkin bir yere sahiptir. Cumhuriyet neslinin batılı anlamda bilgi ve kültür sahibi olmasına katkı sağlamayı amaçlayan dergi, ilgi çekici görselleri, eğlenceli içeriği ve oyun-oyuncak tarifleriyle döneminin öncü çocuk yayınları arasında yer almaktadır. Daha ilk sayısında çocukları önemseyerek değerli gördüğünü açıklayan Sevimli Местиа yayımlandığı on üç sayı boyunca zengin bir içerikle okuyucularının karşısına çıkmayı ilke edinmiş̧tir. Derginin başyazarı Sabiha Zekeriya Sertel'in, ilk sayfada bizde çocukların yeterince önemsenmediğini, hep küçümsendiğini belirterek okurlarına bu dergiyle gereken değerin verileceğini bildirir. Derginin ortaya çıkış amacı Türk çocuk yayıncılığındaki boşluğu doldurmak ve çocuğu merkeze alarak onun pek çok gereksinimini karşılamaya çalışmaktır.

Sevimli Mecmua'nın tüm sayılarında çocukların eğitimine katkıda bulunmak ve onlara okuma sevgisi, yazma becerisi kazandırmak amaçlanır. Bu amacı gerçekleştirmek için de dergide başka milletlerin çocuğa ve eğitime bakışları ele alınarak çocuk gelişimine yönelik önemli bilgiler verilir. Sabiha Zekeriya Sertel'in sosyoloji yükseköğrenimi için Amerika'da bulunması ona önemli bir deneyim ve farklı bakış açıları kazandırmıştır. Yazarın farklı ülkelerde edindiği çocuk eğitimine yönelik izlenimleri ona farklı milletler arasında karşılaştırmalar yapma olanağı sağlar. Sertel, Türk çocuklarının -Amerika'dakinin aksine- pek çok olanaktan yoksun olduğunu düşünür. Bu olumsuz durum bir bakıma derginin ortaya çıkış felsefesini de ortaya koymaktadır: Türk çocuklarını yoksun oldukları oyun ve eğlenceyle tanıştırmak. Sertel'e göre, Avrupa'da ve Amerika'da çocuk değerli olduğunun ve önemsendiğinin bilincindedir. Batılılar çocuklarına büyük adam gözüyle bakarlar ve 
onlara bir yetişkin gibi davranırlar. Onların eğitim sistemi çocuğa birey olma bilinci kazandırmaya ve onu yaşama hazırlamaya dönüktür. Söz konusu gelişmiş ülkelerde çocuklar bağımsız bireyler olarak yetişmekte ve kendi kararlarını alıp uygulama yeterliğiyle donatılmaktadırlar. Sertel'e göre bizde ise çocuk henüz keşfedilmemiş bir varlıktır. Toplumumuz ona küçümseyerek bakar; ancak genç Cumhuriyet, çocuğa hak ettiği değeri ve gereksinim duyduğu yayınları vererek sağlıklı, eğitimli kuşaklar yetiştirmeyi amaçlar.

Eğitim konusu üzerinde özellikle duran Sevimli Мecmua'ya göre bizde eğitim Avrupa'nın, Amerika'nın ve hatta Azerbaycan'ın bile gerisindedir. Dergideki yazılardan okullarımızın gerek öğretmen gerek donanım gerekse de öğretim yöntemleri bakımından oldukça yetersiz oldukları anlaşılır. Sertel'e göre Türkiye'de dayağın ve korkunun egemen olduğu okullarda nitelikli bir eğitim verildiği söylenemez. Çocuklar ilgi ve yeteneklerine göre seçilip kendilerine özgü eğitim programlarında öğrenim görme olanağına sahip değildir. Pek çok çocuk yeteneği ortaya çıkarılamadan klasik bir eğitim modelini sürdürmekte ve sönüp gitmektedir. Oyundan, oyuncaktan ve eğlenceli yayınlardan yoksun çocukların kişilikleri ve zihinleri yeterince gelişememektedir. Sevimli Mecmua' da bu nedenle çocukları eğlendirerek bilgilendirmek esas alınmıştır. Dergide ödüllü bilmece ve bulmacalara yer verilerek okurlar araştırmaya ve öğrenmeye yönlendirilir. Cumhuriyet çocuklarının bilimin kılavuzluğunda çalışkan ve başarılı olmaları derginin temel ülküsüdür. $\mathrm{Bu}$ ülküyü gerçekleştirebilmek amacıyla Edison'dan Markoni'ye varıncaya dek birçok Batılı bilim insanının yaşamöyküleri, icatları ve başarıları dergide ayrıntılı olarak anlatılır.

Sevimli Мecmua pedagoji ve çocuk yayıncılığı alanlarındaki önemli boşlukları görerek bunları karşılamaya yönelik tutarlı bir yayın anlayışı izler. Okurların eğlenerek öğrenmelerini sağlamaya çalışır ve eğitime büyük önem verir. Dergide gezi yazısından öyküye, masaldan efsaneye, yaşamöyküsünden şiire varıncaya dek birçok farklı edebî türde yazıya yer verilir. Okurlarına edebî ve estetik zevk vermenin yanı sıra onların okuma becerilerini de geliştirmeye çalışan dergi, yazma çalışmalarıyla çocukların hayal dünyalarını kâğıda dökebilmelerine de olanak sağlar. Türkçenin eğitimi ve öğretimine yönelik dinleme, konuşma, okuma ve yazma becerilerini geliştirmeye çalışan yazıların yanı sıra, dergide dil bilgisi çalışmalarına da yer verilerek çocukların dil gelişimlerine katkı sağlamak amaçlanır. Dergi, resimli el işi çalışmasından bilmece-bulmaca ve karikatüre, ev ve bahçe oyunlarından oyuncak yapımına dek oldukça zengin bir içerikle okurlarının karşısına çıkar. Söz konusu özellikleriyle Sevimli Мecmua oldukça başarılı bir çocuk dergisi niteliği taşımakta ve çocuk yayınc1lı̆̆ında önemli bir yer edinmektedir.

\section{Kaynakça}

Açıkgöz, K.Ü. (2006). Aktif öğrenme. İzmir: Kanyılmaz Matbaası.

Akdağ, E. (2012). Sevimli Mecmua adlı çocuk dergisi (çeviriyazı, inceleme). Yayımlanmamış yüksek lisans tezi, Afyon Kocatepe Üniversitesi Sosyal Bilimler Enstitüsü, Afyonkarahisar. https://doi.org/10.32709/akusosbil.479290

Arıcı, A.F., Ungan, S. ve Şimşek, T. (2012). "Çocuk edebiyatı türleri ve çocuk eğitimine katkıları.” Kuramdan uygulamaya çocuk edebiyatı el kitabı. (Ed. Tacettin Şimşek). Ankara: Grafiker, 217-322. https://doi.org/10.14527/9786052418086

Çakmak, A. ve Elibol, F. (2013). Çocuk ve oyun. Ankara: Vize.

Çılgın, A. S. (2007). Çocuk edebiyatı, İstanbul: Morpa.

Dedeoğlu, H. (2013). "İlkokullarda çocuk kitapları ve dergileri.” Çocuk edebiyatı. (Ed. Mübeccel Gönen). Ankara: Eğiten Kitap, 285-305.

Dilidüzgün, S. (1996). Çağdaş çocuk yazını, İstanbul: Yapı Kredi. 
Erden, M. (2005). Öğretmenlik mesleğine giriş. İstanbul: Epsilon.

Gürel, Z., Temizyürek, F. ve Şahbaz, N.K. (2007). Çocuk edebiyatı. Ankara: Öncü Kitap. https://doi.org/10.14527/9786053185536

Kavcar, C. (2017). Edebiyat ve eğitim. Ankara: Anı.

Kıbrıs, İ. (2010). Çocuk edebiyatı. Ankara: Kök.

Oğuzkan, A.F. (2013). Çocuk edebiyatı. Ankara: An1.

Okay, C. (1999). Eski harfli çocuk dergileri. İstanbul: Kitabevi.

Piaget, J. (1962). Play, dreams and imitation. New York: W. W. Norton.

Sanders, E. (2008). "Medial art and play therapy with accident survivors." In (C. A. Malchiodi Ed.) Creative interventions with traumatized children. New York: Guilford.

Santrock, J.W. (2012). Yaşam boyu gelişim. (Çev.Ed. Galip Yüksel). Ankara: Nobel.

Sever, S. (2012). Çocuk ve edebiyat. İzmir: Tudem.

Şimşek, T. (2005). Çocuk edebiyatı. Gümüşhane: Suna.

Şirin, M.R. (1998). Çocukluğun kozası. İstanbul: İz.

Uçan, H. (2005). “Çocuk kadar saf, temiz olabilmek/kalabilmek." Hece Çocuk Edebiyatı Özel Sayısı, 104-105: 18-24.

Ungan, S., Arıcı, A.F. ve Şimşek, T. (2012). "Çocuk edebiyatının kaynakları." Kuramdan uygulamaya çocuk edebiyatı el kitabı. (Ed. Tacettin Şimşek). Ankara: Grafiker, 163-217.

Yalçın A. ve Aytaş G. (2016). Çocuk edebiyatı. Ankara: Akçağ.

Yavuzer, H. (2011). Çocuk psikolojisi. İstanbul: Remzi.

Yıldırım, A. ve Şimşek, H. (2013). Sosyal bilimlerde nitel araştırma yöntemleri. Ankara: Seçkin.

Yörükoğlu, A. (2007). Değişen toplumda aile ve çocuk. İstanbul: Özgür. 